\title{
THE IMPLEMENTATION OF LEARNING ORGANIZATION IN ORDER TO INCREASE SUPPLY CHAIN PERFORMANCE IN SPR MAJU BERSAMA BOJONEGORO
}

\author{
Khairul Ikhwan*), Anggraini Sukmawati**), and Eko Ruddy Cahyadi**) \\ *) Master of Management, Faculty of Economics and Management, Bogor Agricultural University \\ Agatis Road, IPB Darmaga Campus, Bogor 16680 \\ **) Department of Management, Faculty of Economics and Management, Bogor Agricultural University \\ Agatis Road, IPB Darmaga Campus, Bogor 16680
}

\begin{abstract}
Sekolah Peternakan Rakyat (SPR) Maju Bersama was formed 3 years ago. SPR Maju Bersama still has some weaknesses in terms of human resource and supply chain performance. Learning organizations are needed for organizations to form an organization that can continuously run independent learning process, so that it has a fast thinking and acting to respond any changes. Therefore, SPR has to implement the learning organization. This paper aims to identify the effect of learning organization on supply chain performance in SPR Maju Bersama. A Model was developed and tested with quantitative and qualitative analysis. A total of 99 members of Sekolah Peternakan Rakyat Maju Bersama were used as data in this study. Quantitative data were analyzed using Structural Equation Mode- Partial Least Square (SEM-PLS). The results showed that learning organization had a positive impact on supply chain performance but not significant. Supply chain driver had a positive and significant impact on supply chain performance. Supply chain driver was significantly impacted by learning organization. Leadership style had a positive and significant impact on learning organization. SPR Maju Bersama needs to optimize its facility and information utility as a strategy to improve its supply chain performance.
\end{abstract}

Keywords: learning organization, supply chain peformance, smallholder farmer, SPR, SEM

\begin{abstract}
Abstrak: Sekolah Peternakan Rakyat Maju Bersama sudah terbentuk 3 tahun yang lalu. SPR Maju Bersama masih memiliki beberapa kekurangan dalam hal sumber daya manusia dan kinerja rantai pasoknya. Organisasi pembelajar dibutuhkan bagi organisasi dalam konteks membentuk organisasi yang dapat terus menerus melakukan proses pembelajaran mandiri sehingga organisasi tersebut memiliki kecepatan berpikir dan bertindak dalam merespon berbagai perubahan yang muncul. Oleh karena itu, SPR harus mempraktikkan organisasi pembelajar. Penelitian ini bertujuan untuk mengidentifikasi dampak organisasi pembelajar terhadap kinerja rantai pasok di SPR Maju Bersama. Model penelitian dikembangkan dan diuji secara kuantitatif dan kualitatif. Total ada 99 orang anggota Sekolah Peternakan Rakyat Maju Bersama yang dijadikan data. Data kuantitatif dianalisis menggunakan structural equation model- partial least square (SEM-PLS). Hasil penelitian menunjukkan bahwa organisasi pembelajar berpengaruh positif terhadap kinerja rantai pasok namun tidak signifikan. Penggerak rantai pasok berpengaruh positif dan signifikan terhadap kinerja rantai pasok. Penggerak rantai pasok secara signifikan dipengaruhi oleh organisasi pembelajar. Gaya kepemimpinan memiliki dampak positif dan signifikan terhadap organisasi pembelajar. SPR Maju Bersama perlu mengoptimalkan penggunaan fasilitas dan informasi sebagai strategi dalam meningkatkan kinerja rantai pasok.
\end{abstract}

Kata kunci: organisasi pembelajar, kinerja rantai pasok, peternak tradisional, SPR, SEM

\footnotetext{
${ }^{1}$ Corresponding author:

Email: khairul_ikhwan45@yahoo.com
} 


\section{INTRODUCTION}

Livestock-agribusiness development should not be separated from the national economic development. The contribution of livestock subsector to the 2016 real GDP (based on constant price) was Rp142.5 trillion. The percentage of livestock subsector to the agriculture subsector was $11.77 \%$. Agriculture's real GDP value in 2016 was Rp1,209.7 trillion (Ditjen PKH, 2016).

The contribution of livestock sector to the creation of employment opportunity is considered to be high. There are about 13 million households owning livestockbusiness which are then named as RTUP (Rumah Tangga Usaha Peternakan). Beef cattle of RTUP produced beef cattle as many as 12.32 million units or about $97.17 \%$ from national population. It shows that most of the national beef cattle population is produced by smallholders (BPS, 2013).

Smallholder livestock businesses have these characteristics: human resources with low competency, low breeder income, implementation of traditional management and technology, relatively low business scale, involvement of family member as human resources, limited usage of farmland to provide grass as forage, saving as beef cattle business motive, and low bargaining position of smallholders in transactions (Yusdja and Ilham, 2006).

Indonesia is a tropical country with huge natural resources and very supportive to the beef cattle business development. However, the rearing of cattle is usually conducted semi-intensively so that it has low productivity. Therefore, the effort of smallholder empowerment becomes important to be conducted. Livestock development needs to be supported by relevant government policies so that it will give positive impact to increase smallholders' welfare (SCI, 2015).

In line with the government effort in developing beef cattle business in Bojonegoro, the Region Government of Bojonegoro through the Official of Livestock and Fishery, in cooperation with Institut Pertanian Bogor (IPB)-worldwide known as Bogor Agricultural University- established Sekolah Peternakan Rakyat (Smallholder Farm School) abbreviated as SPR. SPR was established to realize a smallholder business in a collective company that is managed in one management, and to increase the business competitiveness through the development of knowledge, awareness, and to strengthen the smallholder skills -specifically in animal husbandry.

Sekolah Peternakan Rakyat abbreviated as SPR has a different function from Gabungan Kelompok Tani (Farmer Unity) abbreviated as Gapoktan. Gapoktan is more concerned to be an institution focusing on rising economic scale and business efficiency (Deptan, 2013). SPR is more concerned to be a place for learning together. This kind of place makes a better access for knowledge and technology transfer. Through the SPR, smallholders also expected to change their mindset. The mindset to have an individual business is likely to be changed to the collective business.

SPR Maju Bersama was established three years ago and experienced massive changes. The visible changes included the change in culture and business values, indicating that the smallholders already have a collective business base, and the business tends to be more oriented to profits as well. The changes of values and business culture can be seen from the SPR's motto i.e. "sinau bareng, usaha bareng, untung bareng." (Learning together, working together, and gaining profit together).

The field observations showed that there were some deficiencies in the business field of SPR, one of which was the gap of technical skill and managerial capability among the smallholders. Changes of method and learning processes are needed to face the human resource problem in SPR. The SPR which is directed to be a learning organization attempts to make learning activity able to increase the smallholders' technical skill and managerial capability. Garvin (1993) stated that learning organization has the ability to create and share new knowledge. There is also a literature showing that knowledge management encourages increases of skills and innovation performances (Chen and Huang, 2009).

Field observations also showed that SPR's supply chain performance is still facing some obstacles. The obstacles include (1) that SPR's operational activity has not conducted together, (2) that the small business scale leads to high production costs, and (3) that low market accessibility causes the difficulties for smallholders to obtain reasonably good prices. The empirical research indicated that the application of learning organization is able to improve the supply chain performance. Hult et al. (2006) connected knowledge elements 
including accessibility memory, response quality and learning capacity as keys of supply chain performance. Raisinghani and Made (2005) determined the best decision model among producing, saving, transferring, implicating knowledge and cost, time flexibility and quality as the supply chain performance criteria.

So far, there have been limited empirical literature studies that examined the correlation between learning organization and supply chain performance. Further research on the correlation between learning organization and supply chain performance involving supply chain driver variable has not been conducted yet. Facility, inventory, transportation, information, source and price are already proven to be variables that lead to the increase of the supply chain performance (Shahzadi et al. 2013). Therefore, this study attempts to find the correlation among learning organization, supply chain performance and the supply chain driver. Leader is an important figure to the organization, and so the study needs to consider the impact of leadership on the learning organization. Wesvalia (2015) mentioned that there was a positive and significant impact of the leadership style to the implementation of learning organization.

The literature above became the base of this study. This study aimed at: (1) identifying the impact of learning organization implication on the supply chain performance, (2) identifying the impact of learning organization on the supply chain driver, (3) identifying the impact of supply chain driver on the supply chain performance, and (4) identifying the impact of leadership style implementation on the learning organization.

The study focused on the learning organization management and the supply chain performance of SPR Maju Bersama. For the measurement of learning organization, the study used the theory of Marquardt (2002) with five indicators including learning, organization, people, knowledge and technology. For the measurement of supply chain performance, the study used the theory of Supply Chain Council (2010) with four indicators including plan, source, make and delivery. For the supply chain driver, the study used the theory of Chopra and Meindl (2013) with six indicators including facility, inventory, transportation, information, sourcing and pricing. For the leadership, the study used situational leadership by Blanchard et al. (2013) with four indicators including directing, coaching, supporting and delegating.

\section{METHODS}

This study took place in Sekolah Peternakan Rakyat Maju Bersama, Bojonegoro Regency starting from March to April 2017. The data that used in this study consisted of primary and secondary data. The number of respondent was 99 people consisting of managers and members of SPR Maju Bersama. The primary data were collected by interviewing the respondents using questionnaire while the secondary data were collected from SPR reports and various literature. The data were obtained by census.

The questionnaire used Likert scale. This scale starts from one to five by this explanation: value weight of 5 (strongly agree); value weight of 4 (agree); value weight of 3 (quite agree); value weight of 2 (disagree); and value weight of 1 (strongly disagree). Table 1 was extracted to be the statements in the questionnaire. Questionnaire was made as the tool to collect the desired data. Then, the data were processed with the suitable model on the SEM analysis to achieve the study's aim.

Sekolah Peternakan Rakyat IPB was established to give knowledge to the smallholders about farm technical and non-technical aspects. The expected results from SPR establishment are: (a) the establishment of legal farm collective company that is owned by smallholders organized professionally and proportionally; (b) the appearance of high quality of beef cattle, dairy cattle or poultry in the effort of fulfilling the foods for people; (c) certified cattle breeding to fulfill the needs of the other breeders; and (d) smallholders' sovereignty and higher bargaining position.

The process of SPR Maju Bersama vision and implementation establishment has faced the internal and external changes due to globalization industry trend, information advance, technology development and high competition (Sutisna, 2015). Globalization trend that is characterized by innovation level and high change pushes company to develop knowledge network (Mellat-parrast, 2013). SPR Maju Bersama visions and missions are interpreted as the general description of organization strategy. SPR Maju Bersama strategy is directed to be a learning organization. Operational framework of this study can be seen in Figure 1.

Data analysis methods that were used in this study were descriptive analysis and structural equation 
model-partial least square (SEM-PLS). The latent variables consisted of learning organization, supply chain performance, supply chain driver and leadership (Table 1). Each of the latent variables was measured by the indicator variables.

The literature on the correlation between learning organization and supply chain performance rarely contains empirical proofs. Learning organization is a combination of plan, source, make and delivery. This study tried to connect both variables with the supply chain driver and situational leadership. Situational driver is characterized by six indicators including facility, inventory, transportation, information, sourcing and pricing. Situational leadership consists of these indicators i.e. directing, coaching, supporting and delegating. Framework model of the study is shown in Figure 2.

Based on the discussion of various theories and problems above, this study hypotheses can be formulated as: (1) learning organization impacting supply chain performance; (2) learning organization impacting supply chain driver; (3) supply chain driver impacting the supply chain performance; and (4) leadership impacting learning organization.

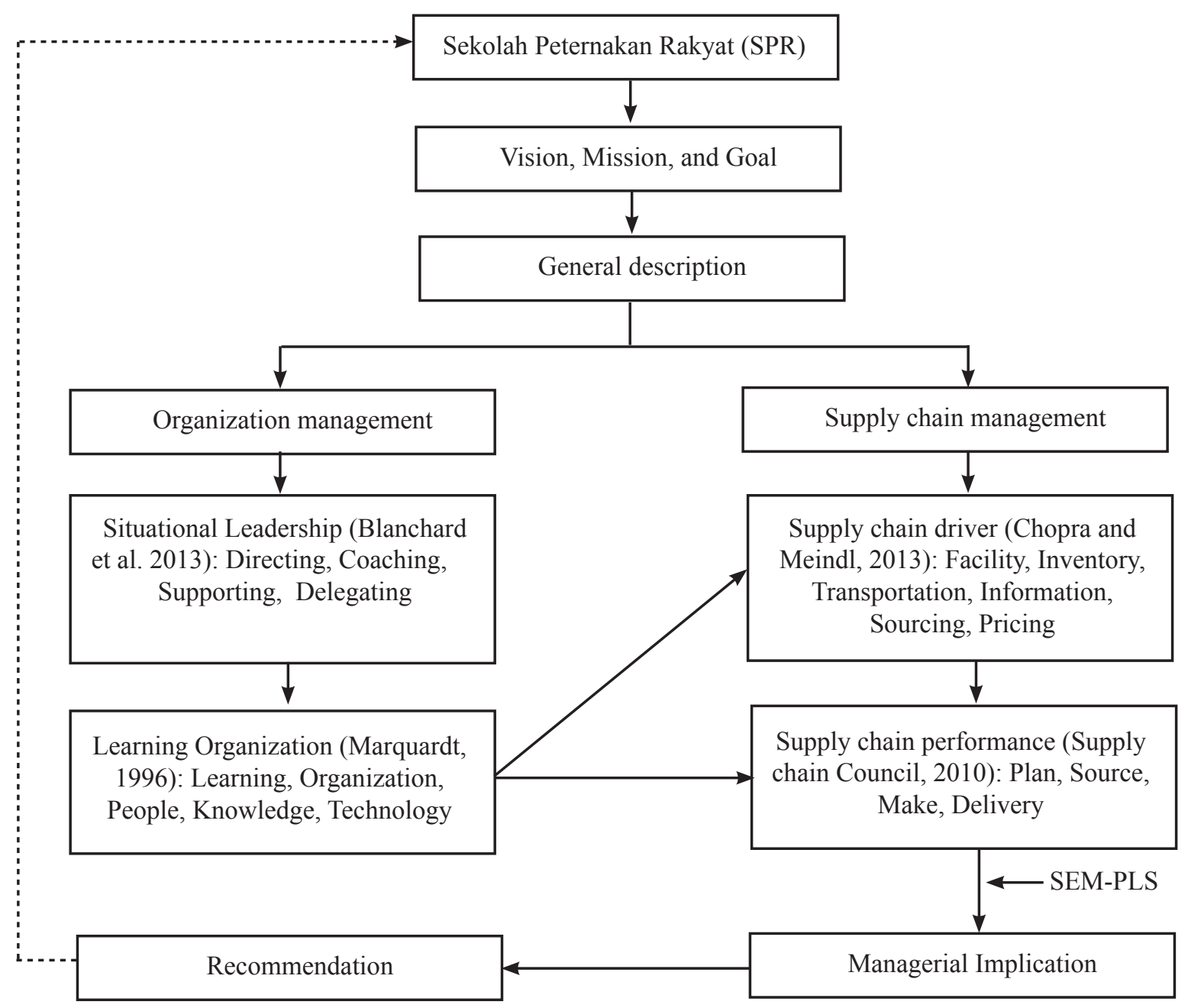

Figure 1. Research framework 
Table 1. Operational definition

\begin{tabular}{|c|c|c|c|}
\hline Variable & Indicator & & Definition \\
\hline \multirow[t]{5}{*}{$\begin{array}{l}\text { Learning } \\
\text { organization }\end{array}$} & Learning (LO1) & $\begin{array}{l}\text { Marquardt } \\
(2002)\end{array}$ & $\begin{array}{l}\text { Learning in the individual, group, and organization level. Skill in } \\
\text { system thinking, mental model, personal mastery, self-directed } \\
\text { learning dan dialogue are important to be optimized in learning } \\
\text { organization }\end{array}$ \\
\hline & $\begin{array}{l}\text { Organization } \\
\text { (LO2) }\end{array}$ & $\begin{array}{l}\text { Marquardt } \\
(2002)\end{array}$ & $\begin{array}{l}\text { The situation where the organization process happens, it is the sub- } \\
\text { system of learning organization }\end{array}$ \\
\hline & People (LO3) & $\begin{array}{l}\text { Marquardt } \\
(2002)\end{array}$ & $\begin{array}{l}\text { Subsystem-people of learning organization consist of head, } \\
\text { administrators, manager, the other farming group and supplier }\end{array}$ \\
\hline & $\begin{array}{l}\text { Knowledge } \\
\text { (LO4) }\end{array}$ & $\begin{array}{l}\text { Marquardt } \\
(2002)\end{array}$ & $\begin{array}{l}\text { Subsystem-knowledge of learning organization controls the } \\
\text { obtained and produced knowledge of the organization }\end{array}$ \\
\hline & $\begin{array}{l}\text { Technology } \\
\text { (LO5) }\end{array}$ & $\begin{array}{l}\text { Marquardt } \\
(2002)\end{array}$ & $\begin{array}{l}\text { Subsystem-technology is built from information that allows } \\
\text { information and knowledge access and exchange }\end{array}$ \\
\hline \multirow[t]{4}{*}{$\begin{array}{l}\text { Supply chain } \\
\text { performance }\end{array}$} & Plan (SCP1) & $\begin{array}{l}\text { Supply Chain } \\
\text { Council (2010) }\end{array}$ & $\begin{array}{l}\text { Planning activity which is regarding a supply chain operational } \\
\text { including feed source, breeding and delivery }\end{array}$ \\
\hline & Source (SCP2) & $\begin{array}{l}\text { Supply Chain } \\
\text { Council (2010) }\end{array}$ & $\begin{array}{l}\text { Order and receive feed and calf; the schedule of delivery and } \\
\text { supply source choosing }\end{array}$ \\
\hline & Make (SCP3) & $\begin{array}{l}\text { Supply Chain } \\
\text { Council (2010) }\end{array}$ & $\begin{array}{l}\text { Activities regarding breeding; from feeding schedule to } \\
\text { delivery; controlling of the complete feed making, complete and } \\
\text { fermentation feed making machine performance; controlling of } \\
\text { stall facility performance }\end{array}$ \\
\hline & $\begin{array}{l}\text { Delivery } \\
\text { (SCP4) }\end{array}$ & $\begin{array}{l}\text { Supply Chain } \\
\text { Council (2010) }\end{array}$ & $\begin{array}{l}\text { Activities regarding order acceptance management process, } \\
\text { transportation tools controlling, route and transportation tool } \\
\text { choosing }\end{array}$ \\
\hline \multirow[t]{6}{*}{$\begin{array}{l}\text { Supply chain } \\
\text { driver }\end{array}$} & Facility (SCD1) & $\begin{array}{l}\text { Chopra and } \\
\text { Meindl (2013) }\end{array}$ & $\begin{array}{l}\text { Physical location such as office building, stall, grassland, feed } \\
\text { storage, and feed processing place }\end{array}$ \\
\hline & $\begin{array}{l}\text { Inventory } \\
\text { (SCD2) }\end{array}$ & $\begin{array}{l}\text { Chopra and } \\
\text { Meindl (2013) }\end{array}$ & All the materials such as calf, concentrate, forage and heifer \\
\hline & $\begin{array}{l}\text { Transportation } \\
\text { (SCD3) }\end{array}$ & $\begin{array}{l}\text { Chopra and } \\
\text { Meindl (2013) }\end{array}$ & Inventory moving from one point to another in the supply chain \\
\hline & $\begin{array}{l}\text { Information } \\
\text { (SCD 4) }\end{array}$ & $\begin{array}{l}\text { Chopra and } \\
\text { Meindl (2013) }\end{array}$ & $\begin{array}{l}\text { stall data and analysis, cattle number, grass and cattle conveyance, } \\
\text { transportation and cattle buyer cost }\end{array}$ \\
\hline & $\begin{array}{l}\text { Sourcing } \\
\text { (SCD5) }\end{array}$ & $\begin{array}{l}\text { Chopra and } \\
\text { Meindl (2013) }\end{array}$ & $\begin{array}{l}\text { Options of the one in charge of artificial insemination, cattle health } \\
\text { management, cattle selling, feed and calf providing }\end{array}$ \\
\hline & Pricing (SCD 6) & $\begin{array}{l}\text { Chopra and } \\
\text { Meindl (2013) }\end{array}$ & $\begin{array}{l}\text { Deciding price strategy using the system including delivery cost } \\
\text { rate or the other price strategy }\end{array}$ \\
\hline \multirow[t]{4}{*}{$\begin{array}{l}\text { Situational } \\
\text { leadership }\end{array}$} & Directing & $\begin{array}{l}\text { Blanchard et al. } \\
\text { (2013) }\end{array}$ & $\begin{array}{l}\text { The style which is characterized by one-way communication from } \\
\text { leader to member and tend to be a direct instruction }\end{array}$ \\
\hline & Coaching & $\begin{array}{l}\text { Blanchard et al. } \\
\text { (2013) }\end{array}$ & $\begin{array}{l}\text { The style which is characterized by two-way communication } \\
\text { between leader and member. Both leader and member take part in } \\
\text { decision making responsibility }\end{array}$ \\
\hline & Supporting & $\begin{array}{l}\text { Blanchard et al. } \\
\text { (2013) }\end{array}$ & $\begin{array}{l}\text { Leader always involves the member to participate in every } \\
\text { working activity }\end{array}$ \\
\hline & Delegating & $\begin{array}{l}\text { Blanchard et al. } \\
\text { (2013) }\end{array}$ & $\begin{array}{l}\text { The style which is characterized by delegating the duties and } \\
\text { authority from leader to member }\end{array}$ \\
\hline
\end{tabular}




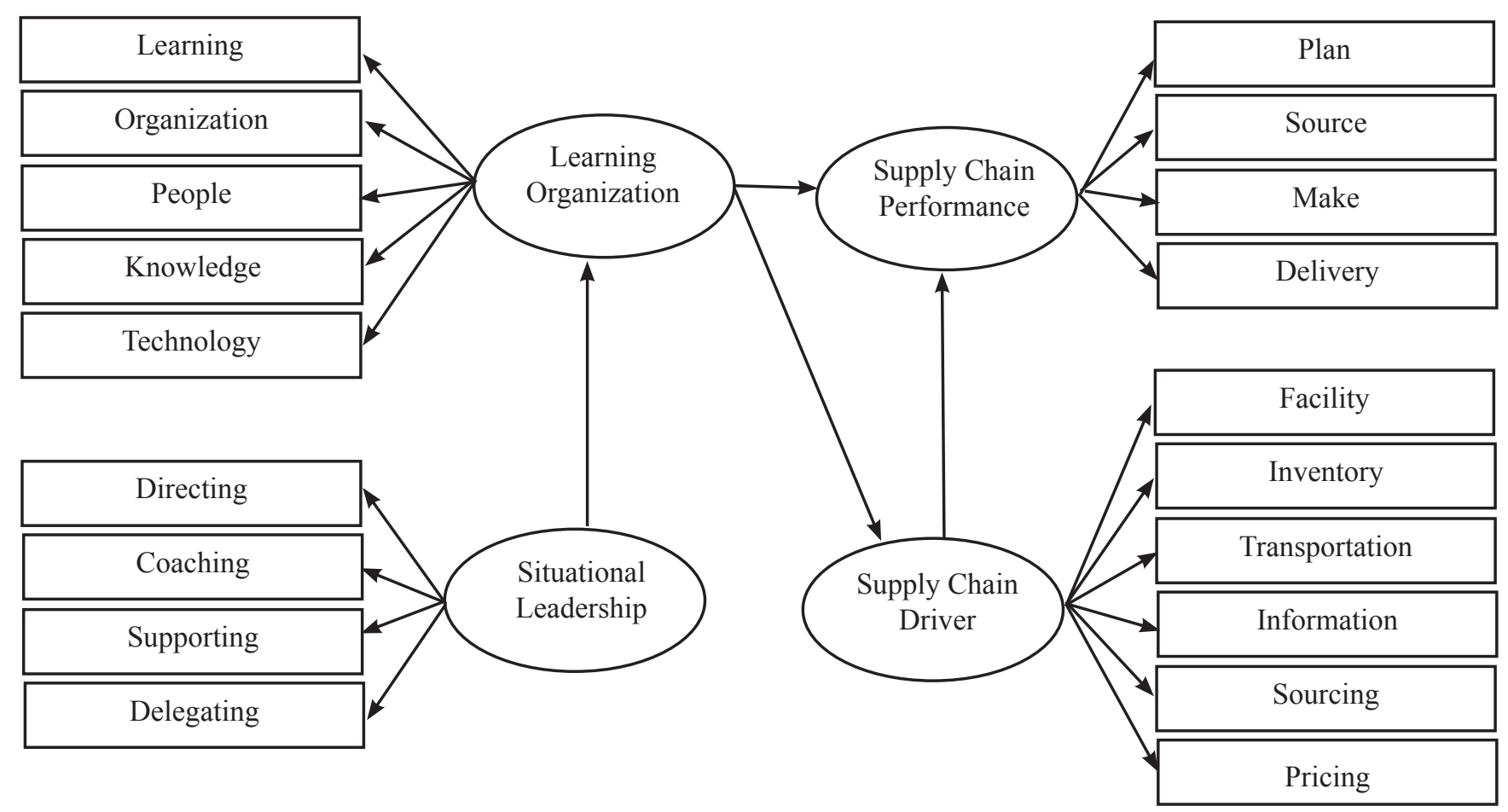

Figure 2. Framework of research model

\section{RESULT}

\section{Measurement Model Evaluation (Outer Model)}

Model evaluation was conducted in two stages i.e. measurement model evaluation or outer model and structural model evaluation or inner model. Measurement model evaluation was carried out in two stages i.e. evaluations on the convergence validity and discriminant validity. Convergence validity was analyzed through three stages i.e. indicator validation, construct reliability and Average Variance Extacted (AVE) value (Ghozali, 2008).

The loading factor value is required to be greater than 0.5 . The indicator that has a loading factor value less than 0.5 has to be excluded from the model (Ghozali, 2008). The indicators that had a loading factor value less than 0.5 included directing $(-0.329)$, coaching $(0.060)$, delegating (-0.453), delivery (0.321), transportation (0.270), and supply (0.428). Re-measurement will be conducted if there is still an indicator that has a loading factor value less than 0.5. Re-measurement has to be carried out to obtain the loading factor value of all reflective indicators to be greater than 0.5 .

The model also is required to have a good validity if each latent variable with their reflective variable has an AVE greater than 0.5 (Ghozali, 2008). There are still latent variables whose AVE value was less than 0.5, so the indicators with the smallest value needs to be excluded from the model (Table 2).

The result of measurement model evaluation on the loading factor is shown in Figure 3. The indicators reflecting learning organization included learning, organization, and people. Knowledge indicator had no ability to reflect the learning organization implementation in SPR Maju Bersana because the breeders tended to have less initiatives in finding the new way to make learning process delivery easier. Technology indicator had no ability to reflect learning organization implementation because of the low usage of computer in increasing breeders' performance.

Indicators reflecting supply chain performance included plan, source, and make. Delivery did not reflect supply chain performance because the simple and careful way of cattle delivery was still less-implemented.

Table 2. Average variance extraxted (AVE) value in the initial model

\begin{tabular}{lc}
\hline \multicolumn{1}{c}{ Variabel } & AVE \\
\hline Situational leadership & 0.510 \\
Learning organization & 0.420 \\
Supply chain driver & 0.284 \\
Supply chain peformance & 0.447 \\
\hline
\end{tabular}




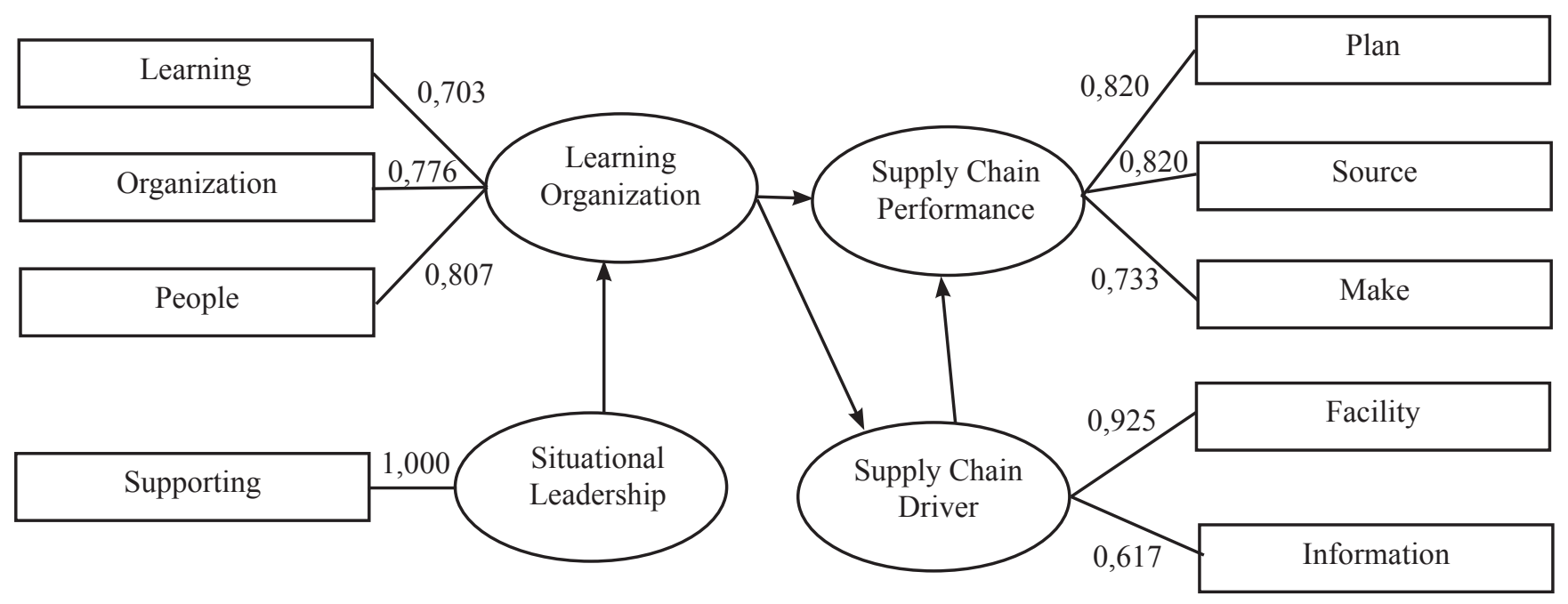

Figure 3. Loading factor in the final model

The indicators that reflected supply chain driver included facility and information. The indicator that had the ability to describe situational leadership was supporting. Knowledge, technology, delivery, directing, coaching, delegating, inventory, transportation, sourcing and pricing were still valid for measuring the latent variable even though they were already excluded from the model.

AVE reflective indicator value had met the requirement of validity. Reflective indicator said to be valid because its AVE value is greater than 0.5 (Table 3). Reliability means a measurement consistency. Based on the reliability test, something is deemed to be reliable if the measurement result of composite reliability to the latent variable is greater than 0.6. Composite reliability value in each latent construct was greater than 0.6 $(0.770,0.803,0.759$, and 0.857$)$. Those reliability values showed that the indicators had the consistency to measure their latent constructs. The loading factor value, AVE value and construct reliability value had met the required values so that the partial least square (PLS) model was deemed to fulfill the requirement of good convergence validity.

Table 3. Average variance extracted (AVE) value, and composite reliability

\begin{tabular}{lcc}
\hline & AVE & Composite reliability \\
\hline Situational leadership & 0.644 & 0.770 \\
Learning organization & 0.577 & 0.803 \\
Supply chain driver & 0.620 & 0.759 \\
$\begin{array}{l}\text { Supply chain } \\
\text { peformance }\end{array}$ & 0.667 & 0.857 \\
\hline
\end{tabular}

Discriminant validity test was conducted by the following principle: different construct manifest variable should not have a high correlation (Ghozali, 2008). Table 4 shows that all of inter-construct correlation values are less than the $\sqrt{ }$ AVE value. Therefore, the model had met the discriminant validity requirement. The AVE value was able to reflect the whole variance numbers in the observed variables (indicators) that was explained by the latent variables.

\section{Structural Model Evaluation (Inner Model)}

According to Ghozali (2008), R-square value is categorized in three stages, namely, weak (0.19), moderate (0.33), and good (0.67). The learning organization's R-square value was 0.138 , which means the PLS model was considered weak in explaining learning organization, while the remaining value of approximately 0.862 was explained by the other factors outside the model. Supply chain driver's R-square value was 0.081, which means PLS model was considered weak in explaining the supply chain driver, while the remaining value of approximately 0.919 was explained by the other factors outside the model. Supply chain performance's R-square value was 0.312 . Supply chain driver's R-square value indicated that PLS model was considered to be in the middle of weak and moderate (between 0.19 and 0.33) for explaining supply chain performance. The remaining value which of approximately 0.688 was explained by the other factors outside the model.

Learning organization and supply chain driver's R-square value in this study was very small so there might be other variables that had better ability in 
explaining learning organization and supply chain driver outside this model. The other variables that might have the better ability in explaining learning organization included knowledge management and selfdirected learning (SDL). SDL creates the collaborationbased initiatives, interactions and teamwork (Rana et al. 2016). The other variable that probably has a better ability in explaining the supply chain driver is supply chain strategy. Supply chain strategy is used to reach the competitive advantage by managing the existing resources.

\section{Learning Organization Role in The Supply Chain Performance}

Bootstrapping result showed that learning organization had a positive impact on loading factor value 0.122 (Table 5), but insignificant to the supply chain performance as its t-statistic value (1.323) was less than t-table (1.96). This study result was not supported by the previous studies. Sangari et al. (2015) showed that there was a mutual correlation between knowledge management process and supply chain performance. Mutual correlation is also found between knowledge management capacity and innovation (Chen and Huang, 2009). Tennant and Fernie (2013) also found the correlation between learning organization and supply chain. Previous studies did not directly show that there is an impact of learning organization on the supply chain performance, but, some variables such as knowledge management process, knowledge management capacity and organizational learning have similar substances with learning organization.
The implementation of learning organization is still probable to be implemented in SPR Maju Bersama but it will not much affecting the supply chain performance. Even though the learning organization had insignificant impact to the supply chain performance but its benefit to the organization is quite huge. The evidence of learning organization benefit is stated in the study that proves the existence of significant impact of learning organization on the organization performance (Aragon et al. 2014; Hussein et al. 2014; Keskin 2006; Rhodes et al. 2008). Learning organization also has the ability to increase business sustainability (Muslim, 2017). The organization that continuously keeps its knowledge management and shares knowledge with each other members also be able to create business sustainability. Those studies prove that there are some benefits in the implementation of learning organization in the any other different variables.

The implementation of learning organization has positive impact on supply chain performance in SPR Maju Bersama. SPR breeders are now having better access in deciding and obtaining the new supply source. Supply factor that needs to be considered are: about how to decide the proper supply and the better access to obtain it. The main supply in beef cattle business is calf and forage source. SPR Maju Bersama was able to easily decide the suitable calf for fattening by observing calf's kind and its body condition. Forage was also easily obtained because SPR Maju Bersama had its self-planted grass and there were many potential forage sources that came from farming waste.

Table 4. Correlation matrix between latent variables

\begin{tabular}{lcccc}
\hline & Situational leadership & Learning organization & Supply chain driver & Supply chain peformance \\
\hline Situational leadership & $\sqrt{ } \mathrm{AVE}=0.803$ & & & \\
Learning organization & 0.406 & $\sqrt{ } \mathrm{AVE}=0.760$ & & \\
Supply chain driver & 0.360 & 0.300 & $\sqrt{ } \mathrm{AVE}=0.787$ & $\sqrt{\mathrm{AVE}=0.817}$ \\
Supply chain peformance & 0.477 & 0.279 & 0.542 & \\
\hline
\end{tabular}

Table 5. Loading factor and total impact R-square value

\begin{tabular}{lccc}
\hline \multicolumn{1}{c}{ Latent variable } & T-statistic & Loading factor & R square \\
\hline Learning organization $\rightarrow$ supply chain peformance & 1.323 & 0.122 & $31.2 \%$ \\
Learning organization $\rightarrow$ supply chain driver & 2.227 & 0.284 & $8.1 \%$ \\
Supply chain driver $\rightarrow$ supply chain performance & 5.753 & 0.512 & - \\
Situational leadership $\rightarrow$ learning organization & 3.100 & 0.372 & $13.8 \%$ \\
\hline
\end{tabular}


Learning organization implementation has encouraged SPR Maju Bersama to make a planning in the form of SOP (Standard Operational Procedure). This plan was made for the implementation of the activities to be controllable and easy-implemented. The planning on complete feed or fermented feed making was detailedwritten. The planning on manure making and waste management was also detailed-written. The planning on calf choosing was decided based on standard too.

Training and learning obtained made them capable in gaining high profits by fulfilling body weight target. SPR gave high quality feeds on time. The forage that was used was fermented pennisetum purpureum (Napier grass or elephant grass), and it became silage and had the efficacy to improve the cattle digestibility. Rice straw was ammoniated to improve the nutrition. Concentrate feed was given to spur the body weight growth. The given concentrate contained bran that was mixed with salt and the drops of cane-waste to accelerate the body weight growth. SPR was keeping its cattle performance properly by washing and routinely checking their health.

\section{Learning Organization's Role on The Supply Chain Driver}

Learning organization loading factor value to the supply chain driver was 0.284 which means learning organization had a positive impact on the supply chain driver (Table 5). The bootstrapping result in table 5 showed that learning organization was able to give a significant impact on the supply chain driver with t-statistic value 2.227 (greater than t-table 1.96). This result showed that the better the implementation of learning organization, the more optimal the supply chain driver is.

Subsystem-learning is the most important subsystem in SPR learning organization that needs to be developed. Farrel (2000) mentioned that high learning orientation leads to the commitment to learn, open-minded character, and various knowledge. Knowledge is able to boost adaptive nature to higher level of learning, and development of product, service and technology.

SPR is continuously giving supports to the breeders to develop their knowledge for both formal and informal learning processes. Breeders received the training either from SPR or outside the SPR. This kind of informal learning becomes the major priority to the small companies (Anderson and Boocock, 2002). SPR encourages the breeders to share the knowledge to each other.

The second-most-important sub-system after learning is people. Breeders have to be empowered so that the learning organization can be realized (Marquardt, 1996). Every breeder is involved in problem solving. Breeder empowerment is implemented by encouraging them to be active in creating new breeding method.

Development in sub-system organization makes it easier for SPR Maju Bersama members to learn with the help of the policies established by SPR Maju Bersama. SPR gives better access in learning process by forming sharing-knowledge-strategy among the members and by giving awards to stimulate member learning motivation.

Knowledge that was obtained from the learning organization activities gave new point of view for the SPR members. They become more considerate to strengthen the facility and information. They realized that technology is a strategic key in the cattle breeding and that it will make their work become easier. They also realized that information is a supporting-source to be competitive. SPR Maju Bersama made the information as a supporting-strategy. Deshpande and Webster (1989) mentioned that strategy development is based on the information. Information is required to identify affordable the feed sources, market demand trend, cattle price changes and information on superior calf sources. Information is necessary to implement the strategic planning in respond to the needs of customer.

\section{Supply Chain Driver's Role in The Supply Chain Performance}

Supply chain driver had positive impact, with the loading factor 0.512 (Table 5), and significant to the t-statistic of supply chain performance which was 5.753 (greater than 1.96). The value of loading factor which was greater than 0.5 indicated that the role of supply chain driver on the improvement of supply chain performance was considered high. SPR Maju Bersama needs to give more attention to the facility and information as a driving aspect of supply chain for the consideration of strategic planning. 
SPR did the facility management to support the cattle breeding activity. Shahzadi et al. (2013) had an opinion that it is important to control facilities in the strategic planning by reducing facility cost. The facilities such as the office building, land and stall used by SPR Maju Bersama are the village assets. The benefit of this is low rental cost. The stall used for breeding place is located near the office building. This location provides a better access for the leaders and breeders to check the cattle. Fattening stall is able to accomodate up to 50 cows. Shahzadi et al. (2013) said that a small 'plant' is less efficient than the bigger 'plant' in term of rental cost and making.

Land boundary is also needed to be noticed in strategic planning. A stall area that has an unused part in it is potential to be modified in the future or simply becomes a parking lot. (Shahzadi et al. 2013). The unused area in front of SPR office building can be used as a Sapronak shop. Sapronak is an abbreviation of sarana produksi ternak (livestock production tools). The area is a wide parking lot so that it is probable to be used as a Sapronak shop.

SPR needs to use the information because it is clear that it has a positive and significant impact to the to the supply chain performance (Munizu, 2017). Rana et al. (2016) mentioned that information increases efficiency by accelerating the work. Nath and Standing (2010) has an opinion that information is able to strengthen the supply chain member. Supply chain members are able to share their resource and skill, create network, learning and innovation, various knowledge, and increase innovation ability.

Information is able to support SPR in finding its qualified and affordable supply source. Information also gave the knowing on the just and profitable selling price for the breeders. Moreover, information encourages the creation of new product innovation.

\section{Situational Leadership Role in The Learning Organization}

Table 5 showed the coefficient value 0.372 . This result showed that situational leadership had a positive correlation with the learning organization. T-statistic value 3.100 was greater than t-table 1.96 for the correlation between situational leadership and learning organization. This result showed that situational leadership had a significant impact on the learning organization. The better the SPR leader's encouragement to the breeder, the better the implementation of learning organization in SPR is. This result was consistent with the findings of Februanto (2008) and Nurwanti (2013). Garvin et al. (2008) stated that the supporting-leadership-style can strengthen the learning in an organization. When the leader is actively make conversations with the members and listens to their opinion through dialogs and debates, the organization member will be feeling encouraged in learning.

Supporting-leadership-style is characterized by leader's willingness to give more chances to their members and give full support for what they need (Blanchard et al. 2013). The implementation of supportingleadership-style in SPR was shown from the act of leaders and breeders that shares the same portion of responsibility in the decision making. SPR leader took part in the activities so that the breeders felt the attendance of the leader. The leader fully did the twoway communication in the organization. This openly two-way communication allowed a better access for breeders to ask the leader on their obstacles.

\section{Managerial Implication}

The creation of learning organization in SPR Maju Bersama needs the role of leadership. The suitable leadership style to be implemented in SPR Maju Bersama is supporting-leadership-style. The leader gives more attention to the breeders that face difficulties in doing their tasks. The leader and the breeders solve the problem so that the breeders' knowledge increases. The leader creates an intense relationship with the breeders so that they have the willingness to improve their way of learning. The leader also encourages the breeders to do self-problem-solving if they are able to finish their task independently.

Learning organization sub-systems that need to be a focus for SPR Maju Bersama improvement include: subsystem-learning, subsystem-organization, and subsystem-people. SPR Maju bersama can create the system that eases the breeders to share their knowledge. SPR Maju Bersama has to support the breeders to improve their knowledge through formal and informal learning. SPR Maju Bersama empowers the breeders by boosting them to be active in creating new breeding methods. 
Supply chain driver has a huge impact on the SPR supply chain performance. Information and facility are the booster of the increase in supply chain performance. SPR Maju Bersama has to optimize the usage of the stall, feed storage, office building and waste treatment unit. SPR Maju Bersama has to keep the stall, storage and office clean and in a good condition. SPR is able to use the information to find the suitable marketing channel. SPR has to use the information to find the superior calf too.

\section{CONCLUSIONS AND RECOMMENDATIONS}

\section{Conclusions}

Learning organization has a positive impact on the increase of supply chain performance but insignificant. The implementation of learning organization has no significant impact on the supply chain performance, but it gives a huge benefit to the organization. Learning organization is still possible to be implemented in SPR Maju Bersama to maintain its business sustainability, product innovation and organization performance.

The implementation of learning organization was proven to have a positive and significant impact to the supply chain driver. The implementation of learning organization creates a better access for the breeders to control the supply chain driver. Learning activity increased the breeders' knowledge on the importance of facility and information. The implementation of learning organization was able to increase the breeders' ability in using the facility and information optimally.

Supply chain driver was proven to have a positive and significant impact on the supply chain performance. The breeders' ability in using facility and information encouraged them to excellently plan their breeding, increase breeding product, and help to provide the best supply.

Situational leadership has a positive and significant impact on the implementation of learning organization. SPR Maju Bersama's leader encouraged the breeders to commit learning. The leader also encouraged them to learn and share their knowledge.

\section{Recommendations}

SPR Maju Bersama has a chance to increase its supply chain performance by optimizing supply chain driver. In the effort of improving supply chain driver, the SPR needs to optimally realize facility, inventory, sourcing, pricing, transportation, and information indicators. Supply chain driver optimization can be conducted by implementing learning organization. For the implementation of learning organization to be well organized, there are five indicators that need to be considered including learning, people, technology, organization and knowledge. The implementation of learning organization is possible to be realized by increasing the role of the leader. For reflecting a good leadership role, a leader needs to optimally realize these four leadership indicators of directing, coaching, supporting and delegating.

For the next study regarding this topic, innovation is possible to be added as a variable that connects the impact of learning organization and supply chain performance. The approach intends to observe the indirect impact of learning organization to the supply chain performance.

\section{REFERENCES}

Anderson V, Boocock G. 2002. Small firms and internationalisation: learning to manage and managing to learn. Human Resources Management Journal 12(2): 5-24. https://doi. org/10.1111/j.1748-8583.2002.tb00068.x.

Aragon MIB, Jimenez DJ, ValleRS. 2014. The mediating role of organizational learning. Business Review Quarterly 73(13): 1-13.

Blanchard K, Zigarmi P, Zigarmi D. 2013. Leadership and the One Minute Manager: Increasing Effectiveness Through Situational Leadership. Ed ke-2. New York: William Morrow.

Basar M. 2016. Sekolah peternakan rakyat semakin memasyarakat http://www.trobos. com. [12 Desember 2016].

[BPS] Badan Pusat Statistik. 2013. Jumlah rumah tangga usaha peternakan menurut wilayah dan jenis ternak. https://www.bps.go.id. [ 1 Agustus 2016].

Chen C, Huang J. 2009. Strategic human resource practice and innovation performance: the mediating role of knowledge management 
capacity. Journal Business Review 62(9): 104114.

Chopra S, Meindl P. 2013. Supply Chain Management: Strategy, Planning and Operations. Ed ke-5. New Jersey: Pearson Prentice Hall.

[Deptan] Departemen Pertanian. 2013. Peraturan Menteri Pertanian Nomor 82/Permentan/ OT.140/8/2013. Jakarta: Departemen Pertanian RI.

Deshpande R, Webster FE. 1989. Organizational culture and marketing: defining the research agenda. Journal of Marketing 53: 3-15. https:// doi.org/10.2307/1251521.

[Ditjen PKH] Direktorat Jenderal Peternakan dan Kesehatan Hewan. 2016. Newsletter Data Makro. http://www.ditjenpkh.pertanian.go.id. [20 Agustus 2017].

Farrell M. 2000. Developing a market-oriented learning organization. Australian Journal of Management 25: 201-220. https://doi. org/10.1177/031289620002500205.

Februanto H. 2011. Pengaruh budaya organisasi kepemimpinan dan organisasi pembelajar terhadap kinerja organisasi, studi pada direktorat IV/ tindak pidana narkoba dan kejahatan terorganisirbareskrim polri. Jurnal Aplikasi Manajemen 9(4):1446-1455.

Garvin DA. 1993. Building a learning organization. Harvard Business Review 71(4): 78-91.

Garvin DA, Edmondson AC, Gino F. 2008. Is Yours Learning Organization?. Human Business Review 86(3): 109-116.

Ghozali I. 2008. Structural Equation Modeling Metode Alternatif Partial Least Square (PLS). Ed ke-2. Semarang: Badan penerbit Undip.

Hult GTM et al. 2006. Knowledge as a strategic resource in supply chains. Journal of Organization and Management 24(5): 458-475.https://doi. org/10.1016/j.jom.2005.11.009.

Hussein N, Mohamad A, Noordin F, Ishak NA. 2014. Learning organization and its effect on organizational performance and organizational innovativeness: a proposed framework for Malaysian public institutions of higher education. Procedia Social \& Behaviour Science 130: 299-304. https://doi.org/10.1016/j. sbspro.2014.04.035.

Keskin H. 2006. Market orientation, learning orientation, and innovetion capabilities in SMEs: an extended model. European Journal of Innovation Management 9(4): 396-417. https:// doi.org/10.1108/14601060610707849.

Marquardt M. 1996. Building the Learning Organization, a System Approach to Quantum Improvement and Global Success. Ed ke-2. New York: Mc. Graw Hill Book Inc.

Marquardt M. 2002. Building the Learning Organization, a System Approach to Quantum Improvement and Global Success. Ed ke-5. New York: Mc. Graw Hill Book Inc.

Mellat-Parast M. 2013. Supply chain quality management: An inter-organizational learning perspective. International Journal of Quality \& Reliability Management 30(5): 511-529. https:// doi.org/10.1108/02656711311315495.

Munizu M. 2017. Pengaruh kepercayaan, komitmen dan teknologi informasi terhadap kinerja rantai pasokan (studi kasus IKM pengolah buah markisa di kota Makassar. Jurnal Manajemen dan Agribisnis 14(1): 32-42. https://doi. org/10.17358/jma.14.1.32.

Muslim MI. 2017. Penerapan organisasi pembelajar terhadap keberlangsungan UKM klaster kerajinan batik Cirebon [tesis]. Bogor: Sekolah Program Pascasarjana, Institut Pertanian Bogor.

Nath T, Standing C. 2010. Drivers of information technology use in the supply chain. Journal of Systems \& Information Technology 12(1): 70-84. https://doi.org/10.1108/13287261011032661.

Nurwanti.2013. Peran pemimpin, organisasi pembelajar dan kompetensi organisasi, serta dampaknya pada kinerja organisasi. Jurnal Bisnis \& Akuntansi 15(2): 177-186.

Raisinghani MS, Meade LL. 2005. Strategic decisions in supply-chain intelligence using knowledge management: an analytic-network-process framework. Supply Chain Management: An International Journal 10(2):114-121. https:// doi.org/10.1108/13598540510589188.

Rana S, Ardichvili A, Polesello D. 2016. Promoting selfdirected learning in the learning organization: tools and practices. European Journal Training \& Development 40(7): 1-38. https://doi. org/10.1108/EJTD-10-2015-0076.

Rana SMS, Osman A, Halim MSA. 2016. Drivers of retail supply chain efficiency: Moderating Effect of Lean Strategy. International Journal of Suppply Chain Management 1(5): 52-62.

Rhodes J. 2008. An integrative model of organizational culture and social capital on effective knowledge transfer and perceive organizational performance. Journal of Work Life 20(4): 245-258. 
Jurnal Manajemen \& Agribisnis, Vol. 15 No. 1, March 2018

Permalink/DOI: http://dx.doi.org/10.17358/jma.15.1.96

Available online at http://journal.ipb.ac.id/index.php/jmagr

Sangari MS, Hosnavi R, Zahedi MR. 2015. The impact of knowledge management on supply chain performance: an emperical study. The International Journal of Logistics Management 26(3): 603-626. https://doi.org/10.1108/IJLM09-2012-0100.

Shahzadi I, Amin S, Chaudhary KM. 2013. Drivers of supply chain performance enhancing organizational output: an exploratory study for manufacturing sector. European Journal of Business \& Management 14(5): 53-64.

[SCC] Supply Chain Council. 2010. Supply chain operations reference (SCOR) model, overviewversion 10.0. www.supply-chain.org. [27 Desember 2016].

[SCI] Supply Chain Indonesia. 2015. Industri penggemukan sapi di Indonesia. http://www. supplychainindonesia.com. [20 Agustus 2017].
Accredited by Directorate General of Higher Education (DGHE), Republic of Indonesia No 12/M/Kp/IE/2015

Sutisna H. 2015. Peran modal insani, corporate value, dan good corporate governance melalui kinerja karyawan terhadap kinerja perusahaan di PTPN VII Lampung [tesis]. Bogor: Sekolah Program Pascasarjana, Institut Pertanian Bogor.

Tennant S, Fernie S. 2013. Organizational learning in construction supply chain. Engineering, Construction \& Architectural Management 20(1): 83-98. https://doi. org/10.1108/09699981311288691.

Wesvalia L. 2015. Pengaruh pimpinan transformasional terhadap organisasi pembelajaran dan kreativitas dalam upaya menumbuhkan sikap ambidientrous manajer (studi kasus pada PT Perusahaan Gas Negara (persero) tbk [thesis]. Depok: Universitas Indonesia.

YusdjaY, Ilham N. 2006. Arah kebijakan pembangunan peternakan rakyat. Analisis Kebijakan Pertanian 14(1): 18-38. 